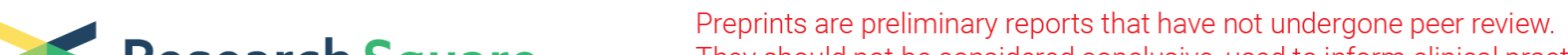 Research Square They should not be considered conclusive, used to inform clinical practice, or referenced by the media as validated information.
}

\section{Construction of Full-Length Infectious Clones of Turnip Mosaic Virus Isolates Infecting Perilla Frutescens and Genetic Analysis of Recently Emerged Strains of Tumv in Korea}

\section{Zheng-Xing Song}

Chungnam National University College of Agriculture and Life Sciences

Su-Jeong Chu

Chungnam National University College of Agriculture and Life Sciences

\section{Eun-Young Seo}

Chungnam National University College of Agriculture and Life Sciences

Wen-Xing $\mathrm{Hu}$

Chungnam National University College of Agriculture and Life Sciences

Yong Pyo Lim

Chungnam National University College of Agriculture and Life Sciences

\section{Tae-Seon Park}

Kangwon National University

Ji-Soo Park

Kangwon National University

Jin-Sung Hong

Kangwon National University College of Agriculture and Life Sciences

In-Sook Cho

Rural Development Administration

John Hammond

USDA-ARS United States National Arboretum

\section{Hyoun-Sub Lim ( $\square$ hyounlim@cnu.ac.kr)}

Chungnam National University College of Agriculture and Life Sciences https://orcid.org/0000-0001-5690-3864

\section{Research Article}

Keywords: aroma, Perilla, turnip mosaic virus, brassica pathogen, Nicotiana benthamiana, cDNA

Posted Date: September 14th, 2021

DOI: https://doi.org/10.21203/rs.3.rs-867651/v1

License: (9) (1) This work is licensed under a Creative Commons Attribution 4.0 International License. Read Full License 
Version of Record: A version of this preprint was published at Archives of Virology on March 8th, 2022. See the published version at https://doi.org/10.1007/s00705-021-05356-9. 


\section{Abstract}

Perilla is an annual herb with a unique aroma and taste and has been cultivated in Korea for hundreds of years. Owing to the highly edible and medicinal value of Perilla plants, it has been widely cultivated in many Asian and European countries. Recently, several viruses have been reported to cause diseases in Perilla in Korea, including turnip mosaic virus (TuMV) which is known as a brassica pathogen due to its significant damage to brassica crops. In this study, we determined the complete genome sequences of two new TuMV isolates originating from Perilla in Korea. Full-length infectious cDNA clones of these two isolates were constructed and their infectivity was tested by agroinfiltration on Nicotiana benthamiana and sap inoculation on Chinese cabbage and radish. In addition, we analyzed the phylogenetic relationship of six new Korean TuMV isolates and determined their respective affiliation with the four major groups. We also conducted recombination analysis for isolates recently occurring in Korean using RDP4 software, which provided new insight into the evolutionary relationships among Korean isolates of TuMV.

\section{Introduction}

Perilla (Perilla frutescens Britton), belonging to the family Lamiaceae that is composed of 236 genera and more than 7000 species, is an annual herb with a unique aroma and taste, and has been cultivated in Korea for hundreds of years [1-3]. Perilla is also cultivated in many other countries, such as China, Japan and Vietnam. Futhermore, because of its increasing economic significance, some western countries including Europe, the United States and Russia are growing Perilla [4]. Perilla is a very common and popular leafy vegetable in South Korea, which is usually eaten as a kind of salted vegetable or consumed with barbecued meats [2]. Due to its high edible value, it was reported to be grown widely in South Korea, including Kangwan, Jeollabuk, Gyeongsangbuk, Kyonggi, Jeollanam, Chungchongbuk, Chungcheongnam and Gyeongsangnam province [3, 5].

In addition to its edible value, Perilla has been reported to have the potential to be a medical resource [6-9]. For example, a new substance Pf-gp6 extracted from Perilla was proved to inhibit the replication of HIV-1 [7]. The leaf extract of Perilla was reported to impede SARS-CoV-2 by direct virus inactivation [6]. In brief, Perilla is a very popular plant with high economic value.

In Korea, some pathogens have been found to infect Perilla, resulting in different diseases. Ramularia coleosporii was reported to induce leaf spot on Perilla [10] and Corynespora cassiicola caused stem blight in Perilla [11]. Recently, diseases resulting from plant viruses have been reported in Korea. In Yeongcheon city, Cucumber green mottle mosaic virus (CGMMV) caused mosaic and malformation on Perilla leaves [12]. In addition, turnip mosaic virus (TuMV) was first found to infect Perilla plant in in the Korea in 2020 , inducing mild mosaic and yellowing symptoms [13].

TuMV is known as a brassica pathogen due to its significant damage to brassica crops [14]. Recent research has indicated that TuMV spread from the west to the east across Eurasia from approximately the 17th century CE [15]. In recent years, TuMV has been found continuously to cause diseases in Brassicaceae plants in South Korea, such as Chinese cabbage (Brassica rapa var. pekinensis) and radish (Raphanus sativus) [16, 17].

Investigation of the molecular evolutionary history of TuMV is beneficial for us to study the biological properties of the population of TuMV [18]. Variation in the genomes of viruses results from mutation, recombination, adaptation and selection [18-21]. Recombination is one of the main forces that accelerate the adaptation and variability, usually resulting in the emergence of mutants and virus isolates able to overcome resistance [21]. As the 
development of programs that are utilized to detect recombination based on sequence comparison advances, more and more recombination events in plant RNA viruses have been reported $[14,18,19]$.

In this research, the complete genomes of two new TuMV isolates were characterized, full-length infectious CDNA clones of these two isolates were constructed and their infectivity was tested by agroinfiltration on Nicotiana benthamiana and sap inoculation on Chinese cabbage cv. CR Victory and radish cv. Iljin. Moreover, we investigated the affiliation of six newly collected isolates from Korea by phylogenetic analysis. We found for the first time that recombination events have occurred in Korean TuMV isolates, which helped us better understand the evolutionary relationship among Korean isolates of TuMV.

\section{Materials And Methods}

\section{Sample collection and plant material}

A $P$. frutescens plant sample with typical TuMV-like symptoms including mosaic and chlorosis was observed in Chuncheon city, South Korea (sample collected by Professor Jin-Sung Hong, Kangwon National University). The $N$. benthamiana, and Chinese cabbage and radish plants used in this study were incubated in $25^{\circ} \mathrm{C} \pm 2^{\circ} \mathrm{C}$ with 16 hours of light and 8 hours of dark. All the soil used was sterilized before use.

\section{RNA extraction, CDNA synthesis and PCR detection}

For virus detection, total RNAs of plant tissues were extracted using TRIzol® Reagent (Life Technologies, Carlsbad, CA, USA), and then the extracted samples were preserved at $-70^{\circ} \mathrm{C}$. The cDNAs were produced using LeGene Express $1^{\text {st }}$ Strand $C D N A$ Synthesis System with an oligo dT primer. Then detection was conducted by PCR using TuMV-CP-forward primer (5'-TCT CAA TGG TTT AAT GGT CTG G-3') and reverse primer (5'-AAC CCC TTA ACG CCA AGT AAG-3') [22].

\section{Construction of full-length clones of TuMV}

To obtain infectious clones, we performed full-length PCR. The PCR mixture of $50 \mu \mathrm{l}$ was composed of $2 \mu \mathrm{l}$ of the template cDNA, $25 \mu$ l of $2 \times$ PCR buffer for KOD FX Neo, 10 pmol of forward primer containing Apal site and T7 RNA polymerase promoter sequence (5'-GAG GGG CCC TAA TAC GAC TCA CTA TAG GAA AAA TAT AAA AAC TCA ACA CAA CAT ACA CAA AAC G), $0.4 \mathrm{mM}$ dNTPs, 10 pmol of reverse primer containing $X$ mal site (5'-GAG CCC GGG TTT TTT TTT TTT TTT TTT TTT TTT TTT TTT GTC CCT TGC ATC CTA TCA AAT G)[17], $1 \mu$ l of Taq polymerase (KOD FX Neo, Toyobo, Osaka, Japan). A cDNA template of TuMV that has been successfully amplified before was used as a positive control. Conditions of full-length PCR were $94^{\circ} \mathrm{C}$ for $2 \mathrm{~min}$ followed by 5 cycles of $10 \mathrm{~s}$ at $98^{\circ} \mathrm{C}$, $30 \mathrm{~s}$ for annealing at $59^{\circ} \mathrm{C}, 6 \mathrm{~min}$ for extension at $68^{\circ} \mathrm{C}$, and then by 30 cycles of $10 \mathrm{~s}$ at $98^{\circ} \mathrm{C}, 30 \mathrm{~s} \mathrm{at} 65^{\circ} \mathrm{C}, 6 \mathrm{~min}$ at $68^{\circ} \mathrm{C}$, and finally incubation at $4{ }^{\circ} \mathrm{C}$. Analysis of full-length PCR products was conducted by $0.8 \%$ agarose gel electrophoresis with dye incorporated in the gel. The PCR product was digested by Apal and Xmal and subsequently cloned into the binary vector pJY which was digested by the same enzymes $[23,24]$. The recombinants were screened by colony PCR and double enzyme digestion. Then the recombinant plasmids were transformed into E.coli competent cell (DH5a).

\section{Agrobacterium infiltration and sap inoculation}


The recombinant plasmids were transformed into Agrobacterium tumefaciens GV2260. The colonies of each clone were incubated on LB plates supplemented with Kanamycin and Rifamycin and then the Agrobacterium cells collected from fresh plates were diluted to approximately OD600 = 0.6 in infiltration buffer (10 mM MES, $10 \mathrm{mM}$ $\mathrm{MgCl}$, and $150 \mu \mathrm{M}$ acetosyringone). $N$. benthamiana plants inoculated with constructed clones were incubated in a growth chamber at $24-26^{\circ} \mathrm{C}(16 / 8 \mathrm{~h}$, light/dark cycle) [17]. Leaves of the infiltrated $N$. benthamiana plants with symptoms were used to inoculate Chinese cabbage cv. CR Victory and radish cv. Iljin as described previously [17].

\section{Sequencing of TuMV infectious cDNA clones}

After the infectivity of each full-length cDNA clone was assessed by agroinfiltration, the full-length clones that have infectivity were sequenced by BIONEER CORPORATION (Daejeon, South Korea). Sequencing was initiated from each terminus using vector specific primers, and continued using primers designed from the obtained sequences (Table 1). The complete genome sequences were compared and assembled in DNAMAN software (Version 5.2, Lynnon BioSoft).

\section{Construction of phylogenetic tree.}

The Maximum-likelihood method was utilized to construct phylogenetic tree with 1000 bootstrap replicates in MEGA software (version 7.0). The complete genome sequences of TuMV strains utilized in this study were collected from NCBI (Table 2), including isolates previously reported in South Korea [16, 17, 25] and 6 newly collected isolates (two each from Perilla, radish, and Chinese cabbage)

\section{Recombination analysis}

Firstly, complete genome sequences of all Korean TuMV isolates were aligned by clustal X in MEGA 7.0. Recombination analysis was performed using RDP4 software package and employed seven detection methods: RDP [26], GENECONV [27], Bootscan [28], Maxchi [29], Chimaera [30], SiScan [31], and 3SEQ [32]. Recombination events were noted if supported by at least four different methods ( $p$-values $<1.0 \times 10^{-6}$ ) [18].

\section{Results}

\section{Construction of full-length cDNA clones}

The full-length PCR products amplified from Perilla were evaluated by gel electrophoresis (Fig 1A), and then the PCR products were digested using Apal and Xmal. Subsequently, the digested product was ligated with the pJY vector which was treated with the same enzymes. Colony PCR was performed to screen the colonies harboring recombinants (Fig 1B), and finally we obtained 5 positive colonies which were also confirmed by double enzyme digestion, namely KPF-1, KPF-2, KPF-3, KPF-4 and KPF-5 (Fig 1C).

\section{Results of agroinfiltration test and sap inoculation}

At 4 days post inoculation (dpi), we observed weak leaf curling symptoms on the top leaves of $N$. benthamiana plants inoculated by KPF-2 while no symptoms were observed in plants infiltrated with other isolates. At $6 \mathrm{dpi}$, plants inoculated by construct KPF-1 also showed symptoms. Symptoms were further recorded at 7, 10 and $14 \mathrm{dpi}$ (Fig 2A). Finally, infectivity was only confirmed for full-length cDNA clones KPF-1 and KFC-2. KPF-2 was shown to cause symptoms more quickly and induced obvious chlorosis which was not induced by KPC-1. The infection was 
confirmed by RT-PCR as described previously, and the RT-PCR result was consistent with their symptom development (Table 3).

For sap inoculation, both isolates infected radish cv. Iljin systemically, causing mild mosaic symptoms, while neither isolate could infect Chinese cabbage cv. CR Victory systemically (Fig 2B).

\section{Nucleotide and amino acid sequence analysis}

The genomes of isolate KPF-1 and KPF-2 are both composed of 9832 nucleotides excluding the poly (A) tail, and the genome is predicted to encode a polyprotein of 3164 amino acids. However, the complete genome size of TuMV isolates we obtained previously was $9833 \mathrm{bp}$. By contrast, the complete genome sequences of the new isolates reported here lack a base in the $3^{\prime}$ untranslated region (at $9753 \mathrm{nt}$ ). The two isolates shared $99.92 \%$ identity in nucleotide sequence and $99.84 \%$ in amino acid sequence. Alignment analysis revealed that there are 8 nucleotide differences between their genomes which are located in P1 (nt 579), HC-Pro (nt 1279 and 2201 ), P3 (nt 3528 and 3653), $\mathrm{Cl}$ (nt 4419), VPg (nt 6233) and Nla-Pro (nt 6597) respectively. Amino acid alignment showed 5 differences, in P1 (R150S); HC-Pro (D384N and P691H); P3 (R1175Q); and VPg (E2035G) (Fig 3).

\section{Phylogenetic analysis}

Two phylogenetic trees were constructed by using Maximum-likelihood method with 1000 bootstrap replicates in MEGA 7.0. The first phylogenetic tree containing isolates collected from a variety of hosts in multiple countries was divided into four branches, which is consistent with previous studies [18, 19] (Fig 4). In addition, the newly collected Perilla isolates (KPF-1 and KPF-2), and radish isolates (KRS-3 and KRS-8) were grouped together and fell in the Basal-BR group. The Chinese cabbage isolates (KBC-1 and $\mathrm{KBC}-8$ ) were predicted to belong to the World-B group. However, most of the isolates collected from Korea belong to the Basal-BR group. Subsequently, we constructed a second phylogenetic tree which only include Korean TuMV isolates with PVY as the outgroup (Fig 5). Interestingly, four strains previously identified as Basal-BR isolates were clustered with KBC-1and KBC-8 which belonged to the World-B group in the first tree, forming a special branch separated with the other branch composed of only BasalBR isolates

\section{Recombination analysis}

Due to the close correlation between four Basal-BR isolates and two World-B isolates shown by the second phylogenetic tree, we conducted recombination analysis by RDP 4 software, which is a mature and common tool to study the recombination events which have occurred in virus populations.

As we expected, isolates BE, and three highly similar isolates (HJY1, HJY2, and R007, sharing 99.93\% identity in nt) were detected as recombinants supported by all seven detection methods (Fig 6). Three recombination events were indicated. The information for each recombination event is shown in Table 4, with HJY-1 representing the three closely-related isolates HJY1, HJY2, and R007.

\section{Discussion}

P. frutescens, a crop with high economic value, has been studied in recent years. With climate change resulting in rising temperatures, diseases caused by viruses have been reported constantly. More and more attention has been paid to the survey and study on the diseases caused by viruses in Perilla plants. In this research, we collected two TuMV isolates from a Perilla sample collected from Kangwon, South Korea. In addition, the complete genome of 
each isolate was determined, the genomes of both isolates are comprised of $9832 \mathrm{bp}$. Interestingly, they lack a nucleotide in the 3' UTR region compared with all TuMV strains we have previously collected in South Korea [16, 17, 23].

In addition, we successfully constructed full-length infectious clones of these two isolates, namely KPF-1 and KPF2. Their infectivity was evaluated by agroinfiltration on $N$. benthamiana. Both isolates are able to infect $N$. benthamiana systemically, but isolate KPF-2 induced symptoms more quickly, usually two days earlier than isolate KPF-1. Amino acid sequence alignment suggested that there are 5 amino acid differences located in P1, HC-Pro (2), P3 and VPg regions. One conserved motif in HC-Pro region has been studied and proved to recruit and employ host ARGONAUTE1 (AGO 1) in the formation of stable virions, which may be involved the efficient systemic infection [33]. The P1 region is the most variable part of the genome [34], it also has been shown to indirectly adjust the RNA silencing suppression activity through reduction of its proteolytic activity which leads to the accumulation of intermediate P1-HCPro [35]. The P3 region also was reported to be an important symptom determinant affecting the host range and cell to cell movement $[36,37]$. Our study provided the complete genome sequences of two new TuMV isolates, and we constructed full-length infectious clones to investigate their corresponding symptom phenotypes on $N$. benthamiana, which is a useful tool in future studies.

Recently, many studies about TuMV have focused on the common recombinants of TuMV and the evolutionary history of the virus [18]. Besides, some phylogenetic studies have emphasized the utilization of non-recombinant sequences to reduce the 'noise' caused by recombinants during the evolutionary analysis [14].

In this study, we analyzed the phylogenetic relationship of six new Korean TuMV isolates and determined their respective affiliation with the four major groups. In addition, owing to the close relationship among several BasalBR isolates and two World-B isolates, we conducted the recombination analysis for Korean TuMV isolates by RDP4. And the recombinant analysis results suggested that recombination events were detected on isolates BE, HJY1 (and also HJY2 and R007), which is supported by seven detection methods (Fig. 6). The recombinant events 2 and 3 could account for the close relationship among Basal-BR isolates BE, HJY1 (plus HJY2 and R007) and World-B isolate KBC-8 (KBC-1). Similar recombinant cases of TuMV have been reported previously, such as the recombination between the Basal-B group and World-B group identified from Australian TuMV isolates [14]. To our knowledge, there are few studies on recombination analysis of Korean TuMV isolates [15], and our analysis provides new insights into the evolutionary relationships among Korean isolates of TuMV.

\section{Declarations}

\section{Conflict of Interest}

The authors declare that they have no conflict of interest.

\section{Ethical approval}

This article does not contain any studies with human participants performed by any of the authors

\section{Acknowledgement}

This work was supported by Korea Institute of Planning and Evaluation for Technology in Food, Agriculture, Forestry and Fisheries (IPET) through Golden Seed Project (GSP), Ministry of Agriculture, Food and Rural Affairs (MAFRA)(213006-05-5-SBL20). 


\section{References}

1. Lee BH, Lee ST, Kim YS (1998) Reference review for the scientific researches on perilla. RDA J Indian Crop Sci 40:80-112

2. Seo WH and Baek HH (2009) Characteristic aroma-active compounds of Korean perilla (Perilla frutescens Britton) leaf. J Agric Food Chem 57:11537-42.

3. Dhyani A, Chopra R, and Garg M (2019) A review on nutritional value, functional properties and pharmacological application of Perilla (Perilla frutescens L.). Biomed Pharmacol J 12:649-660.

4. Nitta M, Lee JK, and Ohnishi O (2003) Asian Perilla crops and their weedy forms: Their cultivation, utilization and genetic relationships. Econ Bot 57:245-253.

5. Nitta M, Lee JK, Kang CW, Katsuta M, Yasumoto S, Liu DJ, Nagamine T, and Ohnishi O (2005) The distribution of Perilla species. Genet Resour Crop Ev 52:797-804.

6. Tang W-F, Tsai H-P, Chang Y-H, Chang T-Y, Hsieh C-F, Lin C-Y, Lin G-H, Chen Y-L, Jheng J-R, Liu P-C, Yang C-M, Chin Y-F, Chen CC, Kau J-H, Hung Y-J, Hsieh P-S, and Horng J-T (2021) Perilla (Perilla frutescens) leaf extract inhibits SARS-CoV-2 via direct virus inactivation. Biomed J 44:293-303.

7. Kawahata T, Otake T, Mori H, Kojima Y, Oishi I, Oka S, Fukumori Y, and Sano K (2002) A novel substance purified from Perilla frutescens Britton inhibits an early stage of HIV-1 replication without blocking viral adsorption. Antivir Chem Chemother 13:283-288.

8. Yamasaki K, Nakano M, Kawahata T, Mori H, Otake T, Ueba N, Oishi I, Inami R, Yamane M, Nakamura M, Murata H, and Nakanishi T (1998) Anti-HIV-1 activity of herbs in Labiatae. Biol Pharm Bull 21:829-833.

9. Asada M, Fukumori Y, Inoue M, Nakagomi K, Sugie M, Fujita Y, Tomizuka N, Yamazaki Y, and Oka S (1999) Glycoprotein derived from the hot water extract of mint plant, Perilla frutescens Britton. J Agric Food Chem 47:468-472.

10. Aktaruzzaman M, Afroz T, Choi H-W, and Kim BS (2021) First report of Ramularia coleosporii causing leaf spot on Perilla frutescens in Korea. Plant Dis.

11. Lee HB, Kim CJ, and Mun HY (2009) First report of stem blight on perilla (Perilla frutescens) caused by Corynespora cassiicola in Korea. Plant Dis 93:550-550.

12. Cho I-S, Yoon J-Y, Chung B-N, and Lim H-S (2020) First report of cucumber green mottle mosaic virus infecting Perilla frutescens in Korea and the world. J Plant Pathol 103:347-347.

13. Park SH, Park JS, Park TS, and Hong JS (2020) First report of turnip mosaic virus infecting Perilla frutescens in Korea. J Plant Pathol 102:969-969.

14. Nyalugwe EP, Jones RAC, Barbetti MJ, and Kehoe MA (2015) Biological and molecular variation amongst Australian Turnip mosaic virus isolates. Plant Pathol 64:1215-1223.

15. Kawakubo S, Gao F, Li S, Tan Z, Huang Y-K, Adkar-Purushothama CR, Gurikar C, Maneechoat P, Chiemsombat P, and San Aye S (2021) Genomic analysis of the brassica pathogen turnip mosaic potyvirus reveals its spread along the former trade routes of the Silk Road. Proc Natl Acad Sci U S A 118.

16. Hu W-X, Kim B-J, Kwak Y, Seo E-Y, Kim J-K, Han J-Y, Kim I-H, Lim YP, Cho I-S, and Domier LL (2019) Five newly collected turnip mosaic virus (TuMV) isolates from Jeju Island, Korea are closely related to previously reported Korean TuMV isolates but show distinctive symptom development. Plant Pathol J 35:381.

17. Gong J, Ju HK, Kim IH, Seo EY, Cho IS, Hu WX, Han JY, Kim JK, Choi SR, Lim YP, Hammond J, and Lim HS (2019) Sequence variations among 17 new radish isolates of Turnip mosaic virus showing differential 
pathogenicity and infectivity in Nicotiana benthamiana, Brassica rapa, and Raphanus sativus. Phytopathology 109:904-912.

18. Ohshima K, Tomitaka Y, Wood JT, Minematsu Y, Kajiyama H, Tomimura K, and Gibbs AJ (2007) Patterns of recombination in turnip mosaic virus genomic sequences indicate hotspots of recombination. J Gen Virol 88:298-315.

19. Ohshima K, Yamaguchi Y, Hirota R, Hamamoto T, Tomimura K, Tan Z, Sano T, Azuhata F, Walsh JA, and Fletcher J (2002) Molecular evolution of Turnip mosaic virus: evidence of host adaptation, genetic recombination and geographical spread. J Gen Virol 83:1511-1521.

20. Zhu FX, Sun Y, Wang Y, Pan HY, Wang FT, Zhang XH, Zhang YH, and Liu JL (2016) Molecular characterization of the complete genome of three Basal-BR isolates of Turnip mosaic virus infecting Raphanus sativus in China. Int J Mol Sci 17.

21. Nagy P.D. (2008) Recombination in Plant RNA Viruses. In: Roossinck M.J. (eds) Plant Virus Evolution. Springer, Berlin, Heidelberg, pp 133-156.

22. Hu WX, Seo EY, Cho IS, Kim JK, Ju HK, Kim IH, Choi GW, Kim B, Ahn CH, Domier LL, Oh SK, Hammond J, and Lim HS (2019) Amino acid differences in the N-terminal half of the polyprotein of Chinese turnip mosaic virus isolates affect symptom expression in Nicotiana benthamiana and radish. Arch Virol 164:1683-1689.

23. Han J-Y, Chung J, Kim J, Seo E-Y, Kilcrease JP, Bauchan GR, Lim S, Hammond J, and Lim H-S (2016) Comparison of helper component-protease RNA silencing suppression activity, subcellular localization, and aggregation of three Korean isolates of Turnip mosaic virus. Virus genes 52:592-596.

24. Park C-H, Ju H-K, Han J-Y, Park J-S, Kim I-H, Seo E-Y, Kim J-K, Hammond J, and Lim H-S (2017) Complete nucleotide sequences and construction of full-length infectious cDNA clones of cucumber green mottle mosaic virus (CGMMV) in a versatile newly developed binary vector including both $35 \mathrm{~S}$ and T7 promoters. Virus Genes 53:286-299.

25. Kim I-H, Ju H-K, Gong J, Han J-Y, Seo E-Y, Cho S-W, Hu W-X, Choi SR, Lim YP, and Domier LL (2019) A turnip mosaic virus determinant of systemic necrosis in Nicotiana benthamiana and a novel resistance-breaking determinant in Chinese cabbage identified from chimeric infectious clones. Phytopathology 109:1638-1647.

26. Martin DP, Murrell B, Golden M, Khoosal A, and Muhire B (2015) RDP4: Detection and analysis of recombination patterns in virus genomes. Virus Evol 1: vev003.

27. Sawyer S (1999) GENECONV: a computer package for the statistical detection of gene conversion. http://www. math. wustl. edu/ sawyer.

28. Salminen MO, Carr JK, Burke DS, and McCutchan FE (1995) Identification of breakpoints in intergenotypic recombinants of HIV type 1 by bootscanning. AIDS Res Hum Retroviruses 11:1423-1425.

29. Smith JM (1992) Analyzing the mosaic structure of genes. J Mol Evol 34:126-129.

30. Posada D and Crandall KA (2001) Evaluation of methods for detecting recombination from DNA sequences: computer simulations. Proc Natl Acad Sci U S A 98:13757-13762.

31. Gibbs MJ, Armstrong JS, and Gibbs AJ (2000) Sister-scanning: a Monte Carlo procedure for assessing signals in recombinant sequences. Bioinformatics 16:573-582.

32. Boni MF, Posada D, and Feldman MW (2007) An exact nonparametric method for inferring mosaic structure in sequence triplets. Genetics 176:1035-1047.

33. Pollari M, De S, Wang A, and Mäkinen K (2020) The potyviral silencing suppressor HCPro recruits and employs host ARGONAUTE1 in pro-viral functions. PLoS Pathog 16:e1008965. 
34. Adams MJ, Antoniw JF, and Fauquet CM (2005) Molecular criteria for genus and species discrimination within the family Potyviridae. Arch Virol 150:459-479.

35. Pasin F, Simon-Mateo C, and Garcia JA (2014) The hypervariable amino-terminus of P1 protease modulates potyviral replication and host defense responses. PLoS Pathog 10:e1003985.

36. Chai M, Wu X, Liu J, Fang Y, Luan Y, Cui X, Zhou X, Wang A, and Cheng X (2020) P3N-PIPO interacts with P3 via the shared $\mathrm{N}$-terminal domain to recruit viral replication vesicles for cell-to-cell movement. J Virol 94:e0189819.

37. Suehiro N, Natsuaki T, Watanabe T, and Okuda S (2004) An important determinant of the ability of Turnip mosaic virus to infect Brassica spp. and/or Raphanus sativus is in its P3 protein. J Gen Virol 85:2087-2098.

\section{Tables}

Table 1. Sequences of the sequencing primers designed and used in this study

\begin{tabular}{lll} 
No. & Name & Sequence \\
\hline 1 & KPF_F1 & AGTGCCATTGCGAACCAC \\
\hline 2 & KPF_F2 & CAAGATCTTCAAGGCGAAG \\
\hline 3 & KPF_F3 & TGACGGATAGTGAGTTGTCT \\
\hline 4 & KPF_F4 & AACGGATCACGAAGGCT \\
\hline 5 & KPF_F5 & ATATCCTCAAGACAAACACC \\
\hline 6 & KFP_F6 & ACCGAATAATGAGCTGC \\
\hline 7 & KPF_F7 & ATTCACAGCGTATATTGCT \\
\hline 8 & KPF_F8 & TCTTGAACCAACTCGACC \\
\hline 9 & R1 & AATCTCACCACATGCGCTAA \\
\hline 10 & R2 & TTGGGGAGGTTCCATTCT \\
\hline 11 & R-Cover & ACATCCAGATGAAAGCAG \\
\hline 12 & R3 & GTTCGATCATCCATGCGT \\
\hline 13 & R4 & TTCCATAAATTCCAAGCGGAT \\
\hline 14 & R5 & AGTTCGCAGTCGATATTTC \\
\hline 15 & R6 & TTGGTGCTAATCCAGTGTT \\
\hline 16 & R7 & CATGGAGGTCACACACCT \\
\hline 17 & KPF_R8 & TAACGTTTTATTCCATTTGCC \\
\hline 18 & KPF_R9 & ATACTCGCTTGCTGTGAG \\
\hline 19 & \\
\hline 19
\end{tabular}

Table 2. Details of the TuMV isolates analyzed in this study 


\begin{tabular}{|c|c|c|c|c|}
\hline No. & Accession Number & Isolates & Original Host & Location \\
\hline 1 & AB701698 & BEL1 & Rorippa nasturtium-aquaticum & Belgium \\
\hline 2 & AB093611 & BZ1 & Brassica oleracea & Brazil \\
\hline 3 & D10927 & Q-Ca & Brassica napus & Canada \\
\hline 4 & KF246570 & ZH1 & Phalaenopsis sp & China \\
\hline 5 & AB252106 & CHZJ26A & Brassica campestris & China \\
\hline 6 & AB093627 & HRD & Raphanus sativus & China \\
\hline 7 & AB252103 & $\mathrm{CH} 6$ & Raphanus sativus & China \\
\hline 8 & AB252107 & CZE5 & Brassica oleracea & Czech Republic \\
\hline 9 & AB701703 & DNK3 & Brassica rapa & Denmark \\
\hline 10 & AB701708 & FRA2 & Brassica napus & France \\
\hline 11 & NC 001616 & Potato virus $Y$ & Solanum spp. & France \\
\hline 12 & AB701697 & ASP & Allium sp. & Germany \\
\hline 13 & AB701734 & TIGA & Tigridia sp. & Germany \\
\hline 14 & AB701735 & TIGD & Tigridia sp. & Germany \\
\hline 15 & $A B 701700$ & DEU2 & Raphanus sativus & Germany \\
\hline 16 & AB701699 & DEU1 & Unknown & Germany \\
\hline 17 & AB252117 & GRC42 & Wild Allium sp. & Greece \\
\hline 18 & AB701696 & GK1 & Matthiola incana & Greece \\
\hline 19 & AB701719 & HUN1 & Alliaria petiolata & Hungary \\
\hline 20 & AB440238 & IRNTra6 & Rapistrum rugosum & Iran \\
\hline 21 & AB440239 & IRNSS5 & Sisymbrium loeselii & Iran \\
\hline 22 & AB093602 & IS1 & Allium ampeloprasum & Israel \\
\hline 23 & AB701720 & ITA1A & Brassica ruvo & Italy \\
\hline 24 & AB093598 & $\mathrm{Al}$ & Alliaria officinalis & Italy \\
\hline 25 & AB701721 & ITA2 & Cheiranthus cheiri & Italy \\
\hline 26 & AB701725 & ITA8 & Abutilon sp. & Italy \\
\hline 27 & AB093600 & ITA7 & Raphanus sativus & Italy \\
\hline 28 & AB093601 & Cal1 & Calendula officinalis & Italy \\
\hline 29 & AB252125 & KWB779J & Brassica rapa & Japan \\
\hline 30 & MG200170 & KBJ5 & Raphanus sativus & Korea \\
\hline 31 & MG200169 & KBJ4 & Raphanus sativus & Korea \\
\hline
\end{tabular}




\begin{tabular}{|c|c|c|c|c|}
\hline 32 & MG200168 & KBJ3 & Raphanus sativus & Korea \\
\hline 33 & MG200167 & KBJ2 & Raphanus sativus & Korea \\
\hline 34 & MG200166 & KBJ1 & Raphanus sativus & Korea \\
\hline 35 & KX674727 & HJY1 & Raphanus sativus & Korea \\
\hline 36 & KX674728 & HJY2 & Raphanus sativus & Korea \\
\hline 37 & KX674729 & $\mathrm{KIH} 1$ & Raphanus sativus & Korea \\
\hline 38 & KX674730 & $\mathrm{KIH} 2$ & Raphanus sativus & Korea \\
\hline 39 & KX674731 & GJS1 & Raphanus sativus & Korea \\
\hline 40 & KX674732 & GJS2 & Raphanus sativus & Korea \\
\hline 41 & KX674733 & GJS3 & Raphanus sativus & Korea \\
\hline 42 & KX674734 & GJS4 & Raphanus sativus & Korea \\
\hline 43 & KY111268 & SW1 & Raphanus sativus & Korea \\
\hline 44 & KY111267 & SW2 & Raphanus sativus & Korea \\
\hline 45 & KX674726 & $\mathrm{BE}$ & Raphanus sativus & Korea \\
\hline 46 & KY111274 & DJ1 & Raphanus sativus & Korea \\
\hline 47 & KY111273 & DJ2 & Raphanus sativus & Korea \\
\hline 48 & KY111272 & DJ3 & Raphanus sativus & Korea \\
\hline 49 & KY111271 & DJ4 & Raphanus sativus & Korea \\
\hline 50 & KY111270 & DJ5 & Raphanus sativus & Korea \\
\hline 51 & KY111269 & DJ6 & Raphanus sativus & Korea \\
\hline 52 & KU140420 & R007 & Raphanus sativus & Korea \\
\hline 53 & KU140421 & R041 & Raphanus sativus & Korea \\
\hline 54 & KU140422 & R65 & Raphanus sativus & Korea \\
\hline 55 & MZ570590 & KPF-1 & Perilla frutescens & Korea \\
\hline 56 & MZ570591 & KPF-2 & Perilla frutescens & Korea \\
\hline 57 & MW556024 & $\mathrm{KBC}-1$ & Brassica rapa & Korea \\
\hline 58 & MW556025 & $\mathrm{KBC}-8$ & Brassica rapa & Korea \\
\hline 59 & MW556026 & KRS-3 & Raphanus sativus & Korea \\
\hline 60 & MW556027 & KRS-8 & Raphanus sativus & Korea \\
\hline 61 & DQ648591 & CAR37A & Cochlearia armoracia & Poland \\
\hline 62 & AB701731 & POL2 & Papaver somniferum & Poland \\
\hline 63 & AB701728 & POL1 & Brassica napus oleifera & Poland \\
\hline
\end{tabular}




\begin{tabular}{lllll}
64 & AB701729 & PRT1 & Brassica oleracea acephala & Portugal \\
\hline 65 & AB093606 & RUS1 & Armoracia rusticana & Russia \\
\hline 66 & AB362513 & TUR9 & Raphanus sativus & Turkey \\
\hline 67 & AB701717 & GBR83 & Brassica oleracea & UK \\
\hline 68 & AF169561 & UK1 & Brassica napus & UK
\end{tabular}

Table 3. Results of RT-PCR detection assays of agro-infiltrated Nicotiana benthamiana plants

\begin{tabular}{lll} 
Clone & N. benthamiana & Number tested \\
\hline KPF-1 & + & 3 \\
\hline KPF-2 + & 3 \\
\hline KPF-3 - & 2 \\
\hline KPF-4 - & 2 \\
\hline KPF-5 - & 2
\end{tabular}

Table 4. Recombination events detected among Korea TuMV isolates

\begin{tabular}{|c|c|c|c|c|c|c|c|c|c|c|c|c|}
\hline \multirow{2}{*}{$\begin{array}{l}\text { Event } \\
\text { number }\end{array}$} & \multirow[t]{2}{*}{ Recombinant } & \multirow{2}{*}{$\begin{array}{l}\text { Major } \\
\text { parent }\end{array}$} & \multirow{2}{*}{$\begin{array}{l}\text { Minor } \\
\text { parent }\end{array}$} & \multirow{2}{*}{$\begin{array}{l}\text { Type of } \\
\text { 'recombinant' }\end{array}$} & \multicolumn{8}{|c|}{ Detection methods * } \\
\hline & & & & & $\mathrm{R}$ & G & B & $M$ & C & $S$ & $\mathrm{~T}$ & $p$-value \\
\hline 1 & $\mathrm{BE}$ & $\mathrm{KBC}-8$ & R65 & $\begin{array}{l}\text { World-B x } \\
\text { Basal-BR }\end{array}$ & + & + & + & + & + & + & + & $2.414 \times 10^{-130}$ \\
\hline 2 & HJY1 & GJS & $\mathrm{KBC}-8$ & $\begin{array}{l}\text { Basal-BR x } \\
\text { World-B }\end{array}$ & + & + & + & + & + & + & + & $6.946 \times 10^{-103}$ \\
\hline 3 & $\mathrm{BE}$ & R65 & $\mathrm{KBC}-8$ & $\begin{array}{l}\text { Basal-BR x } \\
\text { World-B }\end{array}$ & + & + & + & + & + & + & + & $7.22 \times 10^{-64}$ \\
\hline
\end{tabular}

${ }^{*} \mathrm{R}=\mathrm{RDP} ; \mathrm{G}=\mathrm{GENECONV} ; \mathrm{B}=$ Bootscan; $\mathrm{M}=$ Maxchi; $\mathrm{C}=$ Chimaera; $\mathrm{S}=$ Siscan; $\mathrm{T}$ = 3Seq.

\section{Figures}




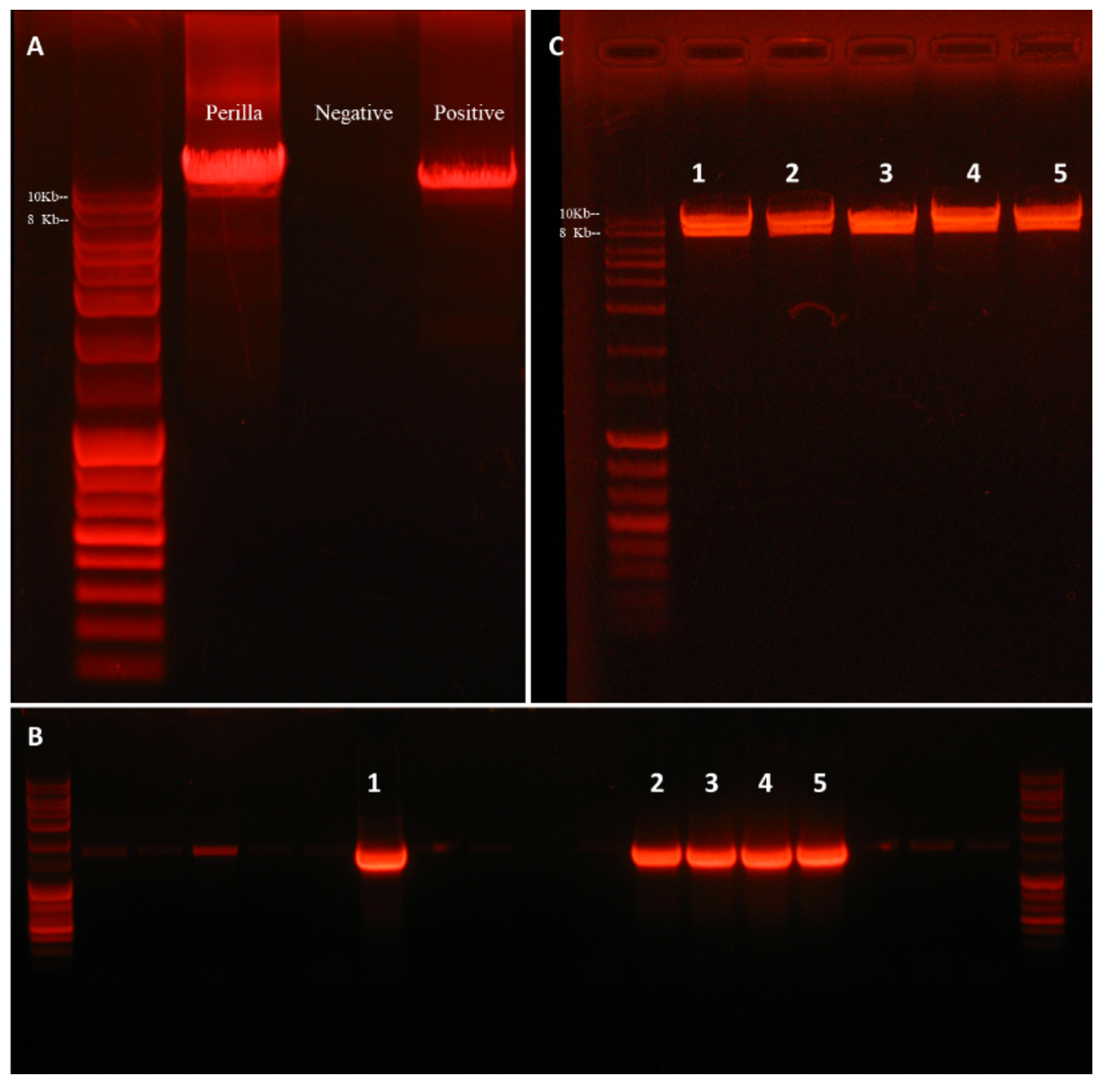

Figure 1

(A) PCR results of amplification of the full-length grenome of TuMV from perilla, with negative and positive controls; cDNA from a TuMV isolate previously amplified successfully served as the positive control. (B) Colony PCR results of screening for full-length TuMV clones. (C) Confirmation of the positive colonies by digestion with Apal and Xmal. 


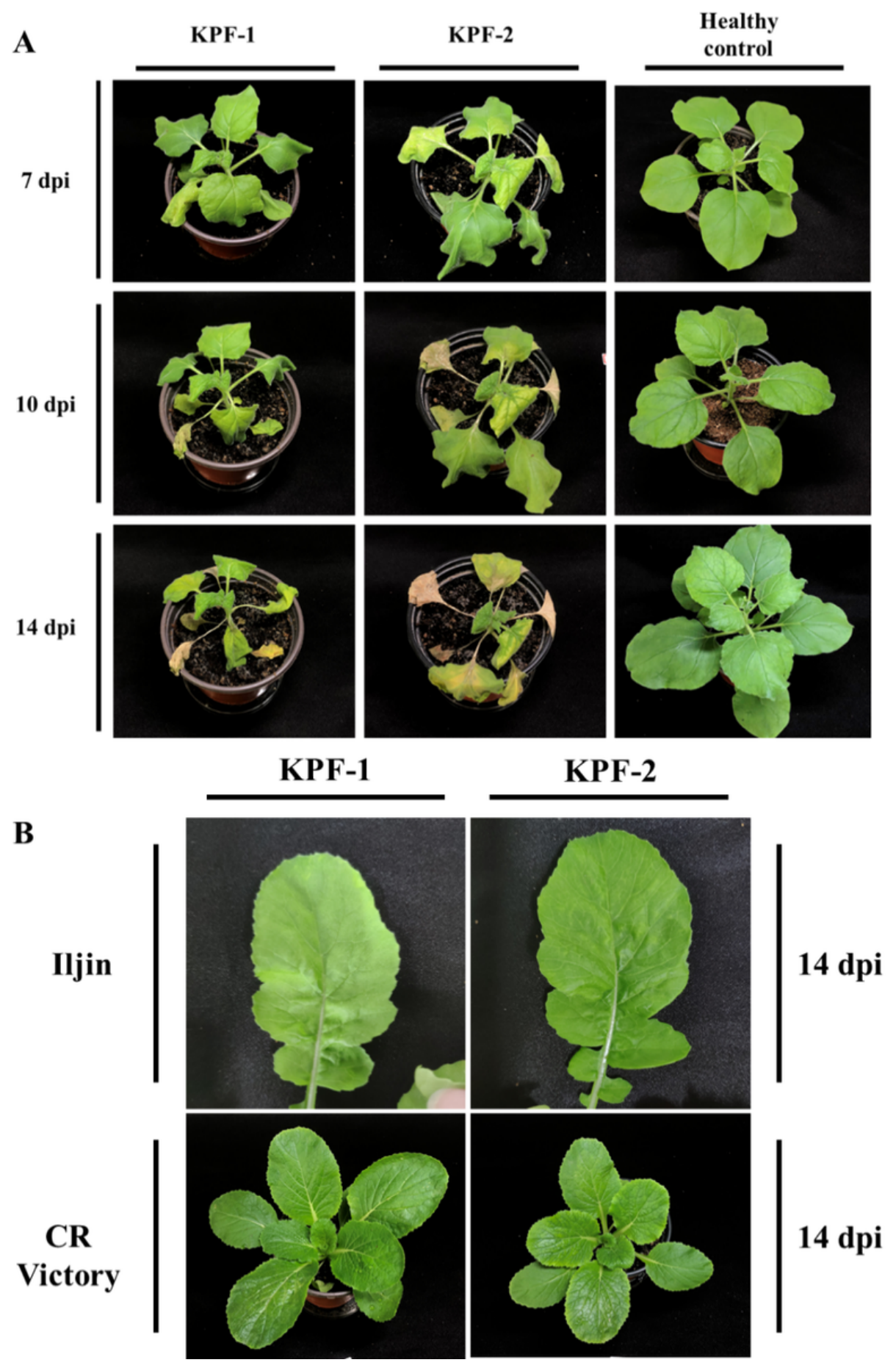

Figure 2

(A) Symptoms induced by TuMV isolates KPF-1 and KPF-2 on Nicotiana benthamiana at 7, 10, and 14 dpi. (B) Symptoms induced by isolates KPF-1 and KPF-2 on radish cv. Iljin and Chinese cabbage cv. CR Victory at 14 dpi. 


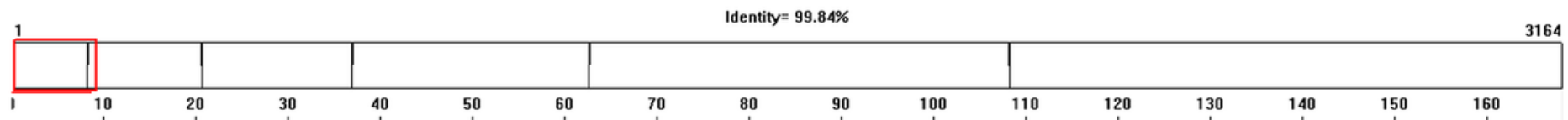
KPF-2

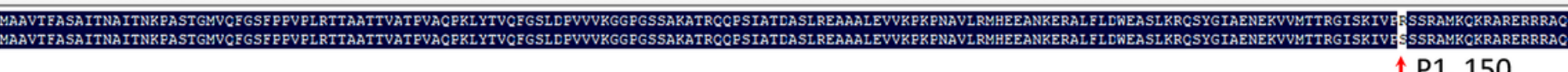

$\uparrow \mathrm{P} 1,150$

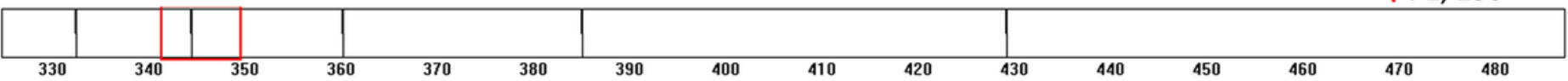

KPF-1

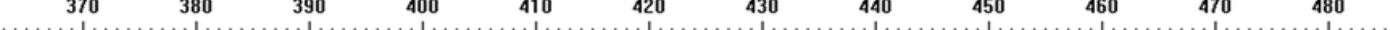

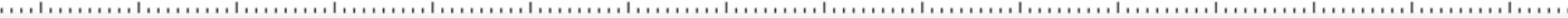

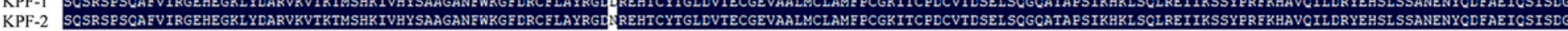
$\uparrow$ HC-Pro, 384

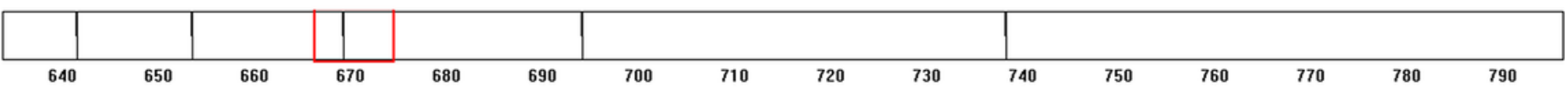

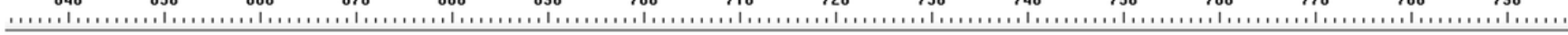

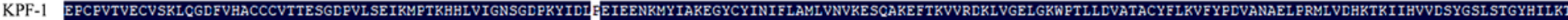

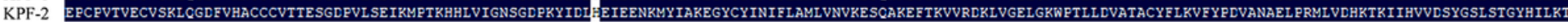
$\uparrow$ HC-Pro, 691

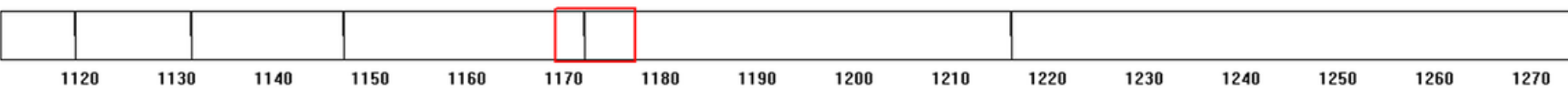

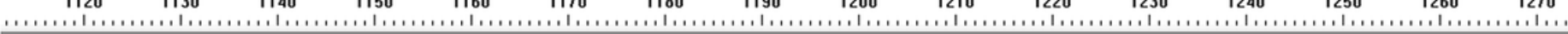

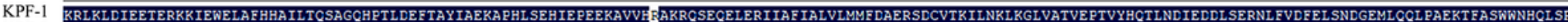
$\mathrm{KPF}-2$

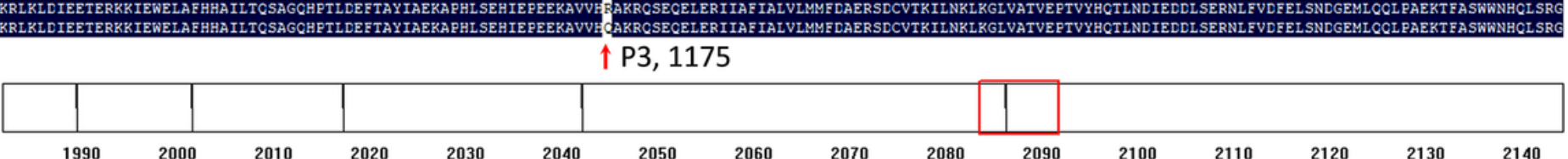

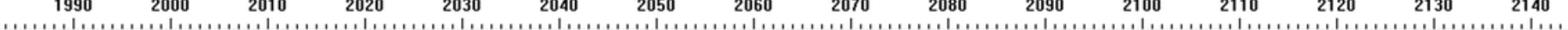

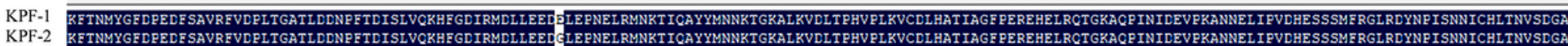
$\uparrow$ VPg, 2035

\section{Figure 3}

The positions of differential amino acids in the polyproteins of TuMV isolates KPF-1 and KPF-2. 


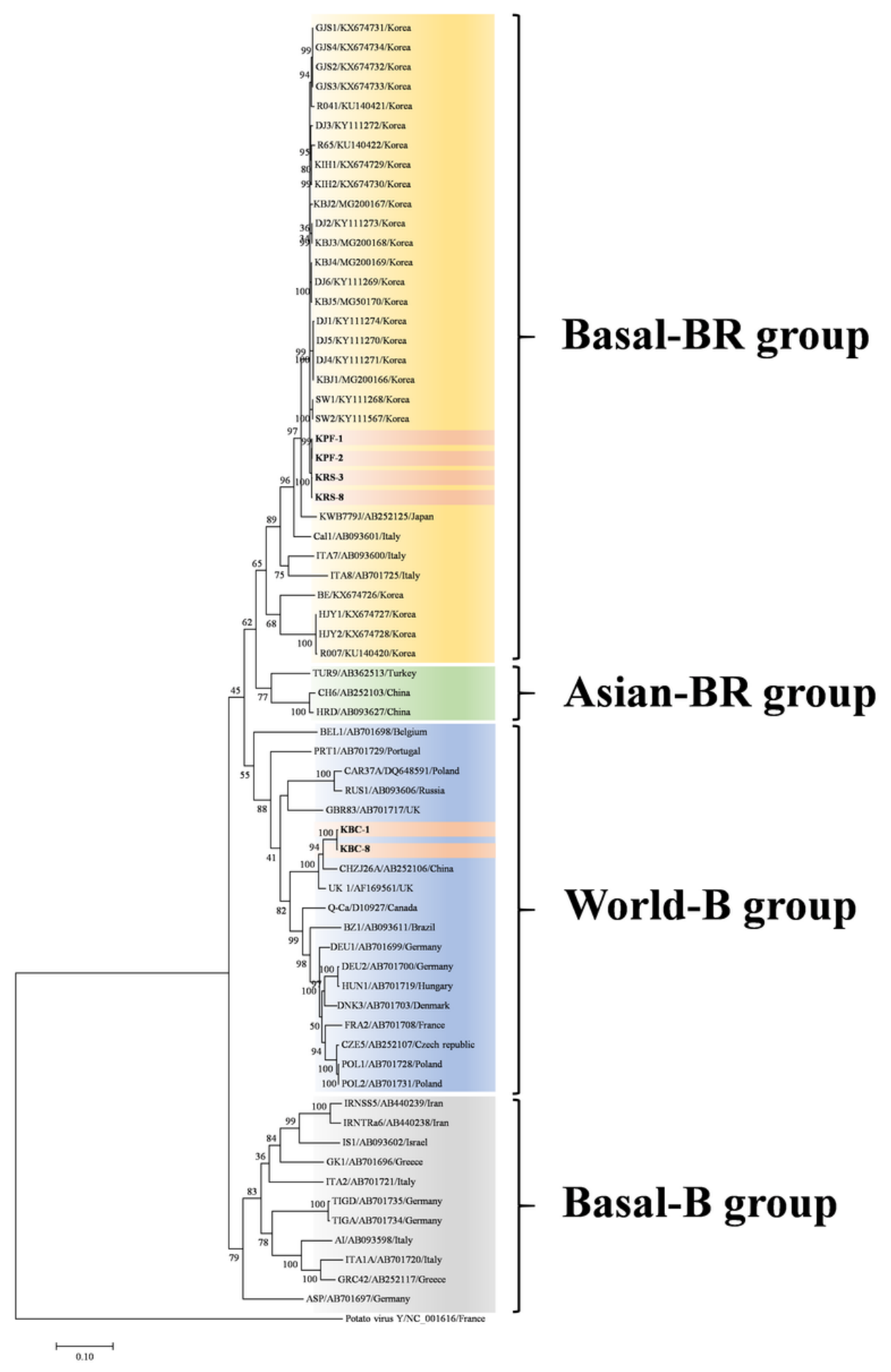

Figure 4

A phylogenetic tree constructed by the Maximum-likelihood method with 1000 bootstrap replicates using MEGA 7.0, based on the complete genome nucleotide sequence of TuMV isolates from around the world. The genome of potato virus $Y$ was used to root the tree. Labels show the isolate name or abbreviation/GenBank accession number/Country of origin; for further details including the host plant, see Table 2. The labels of the new Korean isolates from perilla (KPF-1, KPF-2), radish (KRS-3, KRS-8), and Chinese cabbage (KBC-1, KBC-8) are shown in bold font on pink bars. 
Mungyeong-si

Sangju

Daejeon

Cheonan

Chungiu-si

Jeju

Suwon-si

Chuncheon-si

Boeun-gun

Jeongseon

Buyeo-gun
100

94

GJS3/KX674733

R041/KU140421

DJ3/KY111272

94

80 KIH1/KX674729

99 KIH2/KX674730

- KBJ2/MG200167

DJ2/KY111273

KBJ3/MG200168

KBJ5/MG50170

DJ6/KY111269

KBJ4/MG200169

SW1/KY111268

SW2/KY111567

KPF-1

KPF-2

KRS-3

KRS-8

DJ1/KY111274

DJ5/KY111270

100

DJ4/KY111271

KBJ1/MG200166

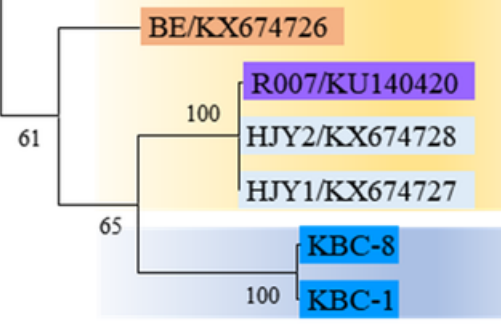

\section{Basal-BR group}

\section{World-B group}

Potato virus Y/NC_001616

0.10

\section{Figure 5}

A phylogenetic tree constructed by the Maximum-likelihood method with 1000 bootstrap replicates using MEGA 7.0 , based on the complete genome nucleotide sequence of Korean TuMV isolates. The genome of potato virus $Y$ was used to root the tree. Labels show the isolate name or abbreviation/GenBank accession number; for further details including the host plant, see Table 2. The labels of the new Korean isolates from perilla (KPF-1, KPF-2), radish (KRS-3, KRS-8), and Chinese cabbage (KBC-1, KBC-8) are shown in bold font. 


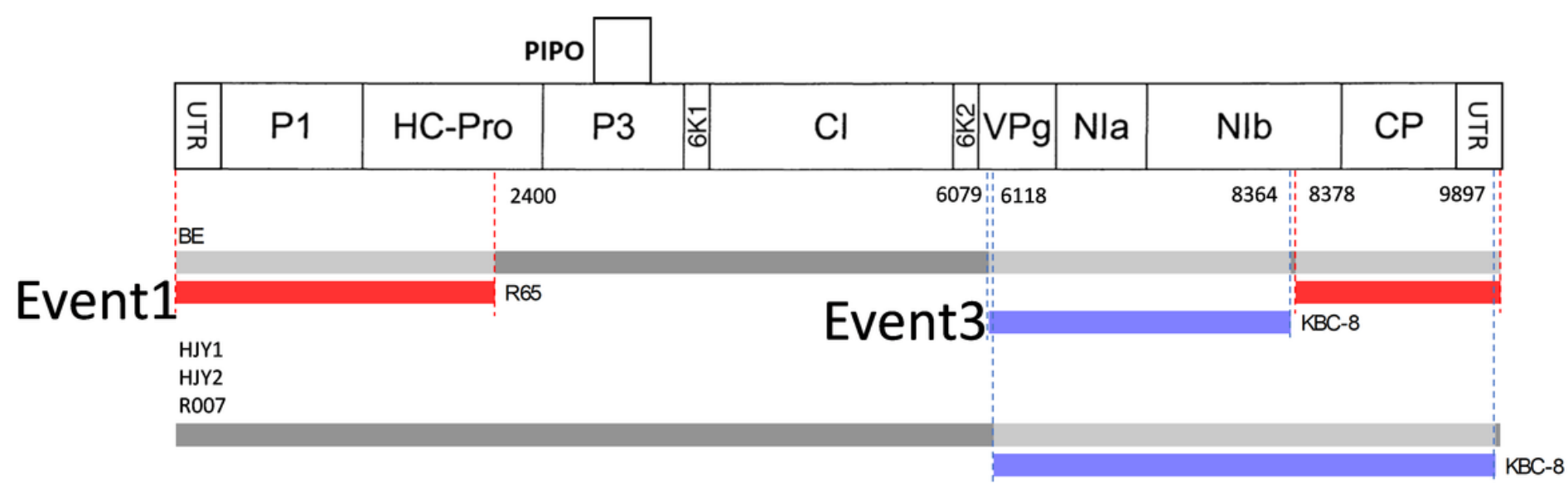

Event2

Figure 6

Recombination events identified using RDP4, and supported by all seven detection methods (see Table 4).

Recombination Events 1 and 3 were detected on isolate BE, and Event 2 was detected in isolates HJY1, HJY2, and R007. 